Bojan Krstić ${ }^{1}$

Jovana Milenović ${ }^{2}$

University of Niš, Faculty of Economics

Tamara Rađenović ${ }^{3}$

University of Niš, Faculty of Occupational Safety
P. 47-58

SCIENTIFIC REVIEW PAPER DOI: $10.5937 / E S D 2101047 \mathrm{~K}$ Received: December 15, 2020 Accepted: February 3, 2021

\title{
MEASUREMENT AND EFFICIENT MANAGEMENT OF ENVIRONMENTAL PERFORMANCES
}

\begin{abstract}
Numerous environmental problems and stakeholder pressures have led companies to accept responsibility for the environmental consequences of doing business. Measuring the environmental performances of companies is gaining in importance and is becoming the subject of analysis in scientific papers and academic circles. Environmental performance indicators enable companies to systematically review and obtain information on the environmental aspect of a company business. If companies take care of the living and working environment, they can increase the motivation of employees and thus increase labor productivity. The aim of this paper is to point out the role and importance of environmental performances of companies, the way they are measured and managed.
\end{abstract}

Key words: environmental performances, measurement of environmental performances, environmental performance management.

JEL classification: $M 48, Q 51, Q 56$

\section{МЕРЕЊЕ И ЕФИКАСНО УПРАВЉАНЕ ЕКОЛОШКИМ ПЕРФОРМАНСАМА}

\begin{abstract}
Апстракт
Бројни еколошки проблеми и притисци стејкхолдера навели су предузећа да прихвате одгворност за последиче обављања пословања по животну средину. Мерење еколошких перформанси предузећа добија на значају и постаје предмет анализе у научним радовима и академским круговима. Показатељи еколошких перформанси омогућавају предузећима систематиски преглед и добијање информација о еколошком аспекту пословања педузећа. Уколико предузећа воде рачуна о животној и радној средини могу повећати мотивачију запослених и тиме повећати продуктивност рада. Циљ рада је да укаже на улогу и значај еколошких перформанси предузећа, начин њиховог мерења и управљања.
\end{abstract}

Кьучне речи: еколошке перформансе, мерење еколошких перфоманси, управљање еколошким перформансама.

\footnotetext{
${ }^{1}$ bojan.krstic@eknfak.ni.ac.rs, ORCID ID 0000-0003-4597-6819

${ }^{2}$ milenovicjovana@gmail.com, ORCID ID 0000-0001-9718-0383

${ }^{3}$ tamara.radjenovic@znrfak.ni.ac.rs, ORCID ID 0000-0003-1632-7772
} 


\section{Introduction}

In contemporary conditions, a large number of companies face environmental pressures from different stakeholders. Besides financial information and after accounting scandals (Enron and WorldCom), stakeholders have also shown interest in non-financial information (environmental performances and other performances of corporate social responsibility). Environmental performance measurement represents an important and very demanding control and management section of a company's management. The measures of environmental performances reflect an interaction between a company's management and the environment. Environmental performance measurements should on the corporate level quantify its effectiveness and efficiency in the field of environmental protection. International organizations and institutions have determined certain instructions and guidelines with the aim of measuring and managing environmental performances. Environmental performance measurement is of great importance to the company because the environmental activities and projects of a company cannot be controlled or directed in a proper way if the eco-effectiveness (eco-efficiency) cannot be measured precisely.

The paper consists of four parts. The first part of the paper contains a review of environmental performances. The second part of the paper focuses on environmental performance measurement. The third part is dedicated to environmental performance management, while, in the fourth part, the focus is on the instruments of environmental performance management.

\section{Environmental performances}

Besides their main business aim (maximizing the worth for the companies' owners), companies should be focused on environmental responsibility in order to eliminate negative impacts which occur as a consequence of their action in the environment. Impacts on the environment occur due to the use of land, resources, energy, and pollutants which are released into air, water and soil during production, distribution, i.e. in a lifecycle of a product (Ienciu, 2009).

Companies dedicate more and more time to the implementation of the concept of corporate social responsibility (CSR). Socially responsible operation implies, first of all, economic success while simultaneously achieving corporate responsibility for environmental and social aspects of the operation (Jovanović, 2017). The concept has evolved from the idea that a company operates not just to make profit, but also to comply with legislation and ethical principles, and to have a tendency to preserve the environment. Therefore, nowadays the environmental dimension of operating, as well as social responsibility, are becoming very important for companies. This demand creates a task and a challenge for company managers - measurement and management of environmental performances.

Environmental performance is defined as the efficiency of a company to fulfil and overcome social expectations regarding the environmental care. This desired goal goes beyond the usual compliance with the current regulations. A proactive approach regarding future environmental questions is particularly important. Environmental 
performance reflects the dedication of an entire organization towards environmental responsibility (Judge, 1998).

The definition of environmental performance also places emphasis on the amount of harming agents which are being emitted from the factories (Klassen, 1999). Environmental performance refers to the identified level of harmful influence on the environment caused by a company. Less harmful influences on the environment lead to better environmental performance and higher corporate environmental responsibility (Lankoski, 2000). Corporate environmental performance can be defined through naturally expressed performances of different company outputs which are related to environmental aspects (the amount of raw material waste, water, $\mathrm{CO} 2$ emissions, etc.) (Wagner, 2003). Environmental performance is defined through certain factors such as: current environmental obligations and risk exposure, potential to use business opportunities which refer to environmental protection, corporate ability to manage environmental risks and possibilities, the use of the system for the management of environmental protection, monitoring of environmental performance and accounting systems, and the quality of environmental reporting (Salo, 2008). All of these factors influence environmental performance. As a consequence, the impact of environmental performance on business (financial) performances of companies is also evident.

\section{Environmental performance measurement}

By measuring environmental performance, the company focuses on measuring impacts on the environment. Based on the results of measurement, the company's management evaluates relevant environmental impacts. Also, the comparison of the target environmental performance with the achieved performance enables the determination of a deviation and decision-making by using corrective actions. Environmental performance measurement is not a simple and easy assignment. It implies the selection of a set of key measures of environmental performance so that they reflect the determined environmental strategy of a company, while acknowledging stakeholders' interests.

\subsection{The concepts of eco-effectiveness and eco-efficiency: the base for the development of a set of environmental performance indicators}

The concept of environmental performance is a wider term than environmental effectiveness and environmental efficiency. Environmental effectiveness implies the success in achieving corporate environmental goals (Krstić \& Vučić, 2004). It refers to the degree of fulfilling the requirements of preserving the environment. Environmental effectiveness can be quantitatively expressed in the following way (Krstić \& Sekulić, 2020):

$$
\text { Eco-effectiveness }=\frac{\text { Planned (target) environmental costs }}{\text { Achieved environmental effects }}
$$

Environmental efficiency refers to the success in the realization of environmental activities. It can be expressed quantitatively (Krstić \& Sekulić, 2020): 


\section{Eco-efficiency $=\frac{\text { Inputs for the realization of environmental actions and programs }}{\text { Achieved environmental effects }}$}

The indicators of environmental performance are quantitative and qualitative (descriptive), financial or non-financial. They provide information on the corporate impact on the environment, the compliance of corporate activities with the environmental regulations, as well as the relations with stakeholders (Chinander K.R., 2001). The system of key indicators of environmental performance should consist of (Krstić \& Sekulić, 2020): 1. Indicators of environmental effects; 2. Indicators of investing into the actions for the improvement of environmental performance; 3. Indicators of environmental effectiveness and environmental efficiency; 4. Indicators of environmental standards achievement; 5. Indicators of compliance in the implementation of the corporate environmental strategy; and 6. Indicators of success in the organization of environmental activities, programs and initiatives.

\subsection{Classifications of environmental performances}

There are many classifications of the indicators of environmental performance present in the literature. In this paper, the emphasis is on the classification of environmental performance indicators according to: 1) Thorsen (1999), 2) ISO 14031 and 3) Global Reporting Initiative - GRI.

The performance indicators according to Thorsen (Thorsen, 1999) are:

a) The performance indicators in a lifecycle of a product. These indicators show the impact on the environment based on the consumption of energy, materials, resources, distribution, transport, use by consumers, waste treatment and consumers' needs contrary to environmental demands;

b) Environmental performance of a chosen production technology. During the selection of production technology, companies should take into account what kind of impact this technology has on the environment, i.e. the company should achieve optimum balance between economic and environmental aspects during the selection of production technology;

c) Environmental performance of the influence of processes, activities and operations on the environment. It is the result of production and management processes in the company and it represents a segment of performance in a lifecycle of products; and

d) Indicators of environmental status, i.e. indicators of environmental performance. Indicators of environmental performance show the influence on the environment by production activities and products on the local and global levels.

The Global Reporting Initiative. and the latest version of the G4 Sustainability Reporting Guidelines include 34 environmental indicators through the following aspects: material, energy, water, biodiversity, emissions, wastewater and sewage, products and services, obeying the law, transportation, and generally, the evaluation of suppliers in terms of environmental impact and the mechanisms for resolving disputes related to the environment (Initiative, G. R., 2013).

ISO 14031 provides guidelines for the development of the tool for monitoring and measuring which is used for the evaluation of the efficiency of protecting the 
environmental system. The standard includes three categories of the environmental performance indicators (Krstić et al., 2012):

1. Environmental condition indicators. These indicators provide information on the condition of the environment on local, regional or global levels. The indicators include receptor indicators (the emission of a substance according to the production volume or the unit of added value) and proxy indicators (showing data on the emission and waste in regard to the influence on the environment);

2. Operational performance indicators. These indicators provide information on the environmental performance of organizational activities. They include indicators such as the investment of the input of materials, energy and services, the work of machinery and equipment, etc.

3. Management performance indicators. These indicators provide information on management's effort to influence the environmental performance of the organization. Within this indicator, the following subcategories have been identified: the implementation of policies and programs, the synchronization of activities with the demands or expectations, the relations with the community, and the financial performance related to the environment.

\subsection{Key indicators of environmental performances}

The set of environmental performance is broad, and only key indicators are listed here as an illustration (Krstić, Sekulić, 2020):

- Indicator of the amount of emitted $\mathrm{CO}_{2}$ (carbon footprint),

- Indicator of the amount of water (water footprint),

- Degree of reduction of raw waste in the production process,

- Level of waste recycling,

- Level of recycling of final products (as the merchandise which was returned by buyers),

- Indicator of the amount of used energy (energy footprint), etc.

The indicator of the amount of emitted $\mathrm{CO}_{2}$ (carbon footprint) is important to measure and control in order to undertake corporate environmental actions and programs, as a type of response of the company's management to the biggest challenge nowadays, which is the impact on climate change and the environment (Marr, 2012). Companies which are not interested adequately in the aim of reducing the emission of gases with the greenhouse effect face bad reputation, profit loss and market share prices. The measurement of emission at the company level should be conducted once a year, or more often. In all larger industries on international and national levels, states usually set the limits of the permitted emission of greenhouse gases. The International Organization for Standardization (ISO) has developed a standard for managing the emission of $\mathrm{CO}_{2}$. Every company should have an intervention plan which will be used in order to decrease the emission of $\mathrm{CO}_{2}$.

Water footprint (measured at a company level) is the amount (expenditure) of used water (directly or indirectly) for business processes and activities (Marr, 2012). Water is nowadays considered a scarce and endangered resource of the planet. The use of water implies the consumption of "green" water (rainfall), "blue" (underground and 
surface water), as well as "grey" (polluted) water. The use of water in many companies is excessive in everyday business operations. Due to this, it is necessary to undertake certain environmental actions with the aim of achieving a more rational use of water.

The degree of reduction of waste material is also a significant environmental indicator, and not just an indicator of efficiency (success) in the sphere of production and the economic area of the cost of waste (disposal, cleaning, etc.). Minimizing these costs goes in favor of the rationalization (reduction) of the production costs and the increase in business competition. In essence, waste is the difference between the amount of raw materials intended for use and the amount of materials actually used for production. Through certain actions and programs, it is possible to reduce the level of waste to a certain degree during a certain period. Otherwise, after an action (program) has been undertaken to reduce waste, the degree of the change (reduction) of waste resulting from this action can be calculated for the current period in relation to the previously observed period (before the action) in the following way:

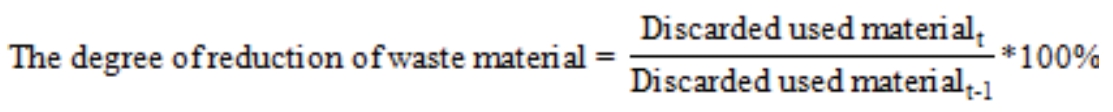

It is of the utmost importance to control waste for certain products and production lines.

The degree of waste recycling shows the amount of waste which is recycled (and used again) in relation to the total amount of generated waste. The monitoring of this degree reflects the tendency to use environmental (and production) management for the improvement of this indicator in order to minimize the unfavorable impact of the inevitably generated waste on the environment. This degree is calculated in the following way:

$$
\text { The degree of reduction of waste recycling }=\frac{\text { The amount of recycled waste }}{\text { The total amount of waste }} * 100 \%
$$

The goal of every company should be recycling and reusing all the generated waste, the increase in the economical level of business activity, as well as, the reduction of the negative environmental impact.

The degree of product recycling is an important environmental indicator of manufacturing companies for products which are no longer used by buyers (users) because they are timeworn, broken, old, etc. Such products have a negative environmental impact. The degree of product recycling is obtained in the following way:

$$
\text { The degree of product recycling }=\frac{\text { The amount of products which is recycled }}{\text { The total amount of sold products }} * 100 \%
$$

The goal of the manufacturing company which is responsible for its own products (which are no longer used by buyers) is to recycle $100 \%$ of their products.

The indicator of the amount of used energy is a significant indicator of corporate environmental responsibility if we take into account that every day the consumption of energy in the world increases, fossil resources decrease, and the price of energy grows (Marr, 2012). Therefore, the programs for preserving energy are very important. Based on their current consumption, companies should set a goal to reduce the usage of energy 
(the amount of consumed energy), and thus reduce the cost as well to a certain degree. The derived indicators of energy efficiency are among the most relevant ones (Benedetti, Cesarotti \& Introna, 2015, 48).

\section{Environmental performance management - concept and key instruments}

On the basis of the aforementioned indicators of environmental performance, it can be inferred that they sum up the information about the environment and that, based on them, the control of the set goals can be conducted and the area which requires the improvement of performance can be determined. A company should adequately choose the key measures of performance from the proposed framework so that it could, with the efficient measuring for management purposes, achieve good performances of the relation with both internal and external stakeholders. Internal stakeholders (managers and employees) can have benefits in the sense that they can set goals more easily and more realistically, monitor the performance of an environmental product, measure the discrepancy in relation to the target performance, identify factors of bad or unsatisfactory performance, and undertake activities in order to continuously improve business processes. The benefits for external stakeholders (from a broader social community) include the regulation, control and supervision of a company by international and national environmental institutions and competent state authorities, as well as the provision of relevant environmental information. Also, other external stakeholders (buyers, suppliers, potential investors) benefit from the environmental performance measurement (Krstić \& Sekulić, 2012), because they receive vital information for their business decisions.

Environmental performance management is the assignment of the company's management sector. Environmental performance management is a continuous process of identification, measurement, development and synchronization of corporate performance with the strategic goals (Aguinis, 2013). The management process is conducted through four stages (Krstić \& Vučić, 2004): 1. Defining target environmental performances. Performance planning is the starting point in environmental performance management. In this stage, a possible negative impact of a company on the environment and the willingness of the company to improve are determined. The goals are set in such a way as to eliminate entirely or reduce the negative impact on the environment. They can be defined at the levels of companies, business units, departments and products (Sharman, 2001). When the plans are determined, the next step is their operationalization with the help of designed environmental programs and projects; 2. Defining environmental actions, projects and programs to accomplish desired goals. In this stage, certain documents are prepared in the form of investment projects, technical procedures, protocols, etc; 3. Environmental revision of undertaken actions, measurement and evaluation of achieved environmental performances. This stage is characterized by the measurement and evaluation of environmental performance in order to determine whether there has been any detour from the target levels of environmental performance, and to measure the current (achieved) environmental performance; 4. Feedback, communication and training related to environmental issues. Based on the feedback regarding the achieved environmental performance, a decision on further everyday activities is made, and there 
is a tendency to improve awareness and strengthen the responsibility of the management sector through educational programs for the exchange of knowledge and information.

A company can improve its competitive position through the efficient management of environmental performance which is based on the following characteristics (Krstić \& Sekulić, 2012):

- Reduction of losses by using environmentally acceptable materials;

- Reduction of costs related to waste and material disposal;

- Implementation of the concept of an environmental product in the design, development and production stages;

- An increase in income by turning waste material into new products;

- Reduction in the use of risky and bio-hazardous materials, due to a timely and adequate system of monitoring and reporting;

- Reuse of materials which can be recycled and returned components of products, by conducting efficient programs for the reverse flow of production.

Figure 1. Strategic environmental performance management

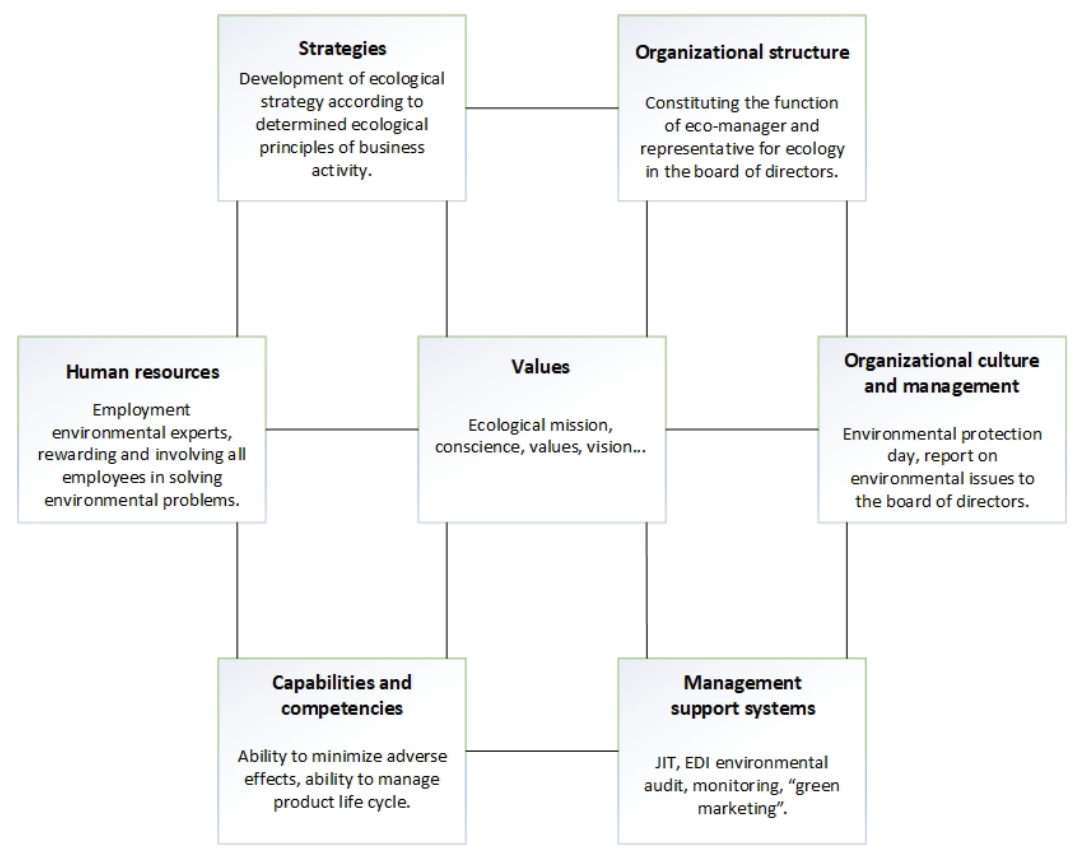

Source: Krstić, B., Vučić, S. (2004a). Upravljanje ekološkim performansama preduzeća. Poslovna politika, 53-57

During the management of environmental performance, companies can use different models. Strategic Environmental Performance Management helps the company to respond to the challenges of environment preservation by designing and conducting programs (projects) for improving environmental performance. The key elements of the system for strategic environmental performance management (Figure 1) include: environmental strategy, organizational structure, human resources, organizational values, organizational culture, capabilities and competencies, and management support systems. 
Through this conceptual framework, a manager can also integrate an environmental dimension into their corporate or business unit strategy. The environmental strategy is a segment of social responsibility and an inevitable area of a competitive strategy, because environmental performances influence the business (financial) performances, image and reputation of a company.

Besides the model for strategic environmental performance management, a company can also use different support systems. A relevant factor in environmental performance management is the application of: cost-benefit analyses, the concept of risk management, environmental issues management, environmental management of total quality, and standards ISO 14001.

The cost-benefit analysis is used to evaluate project justification. It is applied with projects which have direct commercial effects, which can be measured simply and easily, but also with projects which bring indirect benefits and are more difficult to measure. The aim of the cost-benefit analysis is to compare the benefits and costs of a project, to perform its comparison and to evaluate to what extent it is justified for the company. The cost-benefit analysis contributes to a more efficient location of resources through better identification and selection of different regulatory activities and projects (Krstić\&Vučić, 2004). It affects the regulation process by the state authorities and other bodies. It enables decision-making about the selection of the right project for the company. Besides advantages, there are a few flaws such as the occurrence of errors in prediction and errors in measuring and evaluation.

Risk management is one of the instruments of environmental performance management which enables identification and quantification of a risk event. During the process of decision-making about the investments into environmental measures, it is necessary to take into account the necessary costs, but also benefits, of preventing a risk event, which points to the similarity with the cost-benefit analysis.

Environmental issues management enables the compliance of corporate activities with the public interest in the areas of preservation and protection of the environment. During the process of making and conducting previously set plans which refer to environmental issues, their occurrence is minimized (Jugović, 2019).

Environmental total quality management is the synergy of the principles of ecomanagement and total quality management. It implies the following basic principles (Krstić \& Vučić, 2004): recognition of the users' needs, which implies that the quality defines buyers' needs and desires, regulators, eco-groups, and society in general, continuous improvement - a systematic and continuous effort should be provided in order to improve the processes, and the performances of business activities in such a way so that environmental problems are not manifested - a timely recognition, prevention and elimination of potential environmental difficulties enables the recognition of causes of possible problems, a systematic approach in environmental performance management an individual part of the process should be observed as a separate system, i.e. a whole, because every part implies certain resources, techniques and procedures for making decisions.

The ISO 14001 has the aim of encouraging the preservation of the environment and the avoidance of conflicts between different management approaches. Standards connect environmental goals, politics, and systems so that the companies could adequately manage environmental performance. Companies apply this standard if they want to: 
- $\quad$ Apply a systematic approach to environmental management;

- $\quad$ Adjust their business activities and respect environmental principles;

- $\quad$ Comply with the environmental legislation, and

- $\quad$ Receive a certificate for the system of environmental management.

Environmental performance management brings numerous benefits for both the company and the environment, it enables cost reduction, but also increases production and attractiveness to potential investors (stakeholders) (Mladenović \& Arsić, 2017).

\section{Conclusion}

Negative environmental consequences of economic activities have made companies take responsibility for the healthy environment. The costs of the prevention and detection of pollution affect the total amount of costs, which is why companies tend to simultaneously improve both financial and environmental performances and to achieve economic sustainability of their business activities. During the resolution of environmental issues, management should play an essential role. The main motive for management should be the fact that corporate environmental performances affect corporate financial performances, as well as the efficiency of the management. Environmental performance measurement is an important assignment of the management. Properly selected and designed environmental indicators provide a good base for making decisions and achieving sustainable development.

In order for companies to successfully reduce the negative impact on the environment and to improve environmental performance, it is necessary form them to integrate appropriate tools into the process of environmental management. One of the tools which can be useful during the integration of environmental strategy into business strategy is the ISO 14001 standard. This way companies raise environmental awareness within each department, and they are able to improve their environmental performances, effectiveness and profitability. Moreover, the introduction of environmental management accounting contributes to a better connection between the corporate strategy and the environment, which has a long-lasting effect on the protection of the environment. Furthermore, by introducing the appropriate system of calculating environmental costs which were until recently treated as general costs and very often ignored, companies will be able to track environmental costs and manage them. An efficient environmental cost management enables companies to make business decisions more easily. Nowadays, it is an ethical obligation of every management to create a framework for environmental performance measurement and management, to measure and monitor performance, to efficiently direct environmental activities based on the afore-mentioned points, and consequently to choose the forms for reporting on the protection of the environment, be it in an annual report on business activities or in a special report on the protection of the environment or on sustainable development. 


\section{Literature}

Aguinis, H. (2013). Performance management. Upper Saddle River, NJ: Pearson/ Prentice Hall.

Benedetti, M., Cesarotti, V., \& Introna, V. (2015). Improving Energy Efficiency in manufacturing systems: literature review and analysis of the impact on the energy network of consolidated practices and upcoming opportunities. Energy Efficiency Improvements in Smart Grid Components, 41-68.

Chinander, K. R. (2001). Aligning accountability and awareness for environmental performance in operations. Production and Operations Management, 10(3), 276291.

Claver, E., Lopez, M. D., Molina, J. F., \& Tari, J. J. (2007). Environmental management and firm performance: A case study. Journal of environmental Management, 84(4), 606-619.

Dahlsrud, A. (2008). How corporate social responsibility is defined: an analysis of 37 definitions. Corporate social responsibility and environmental management, 15(1), 1-13.

Initiative, G. R. (2013). G4 sustainability reporting guidelines: Reporting principles and standard disclosures. Global Reporting Initiative, Amsterdam, 7-14

Ienciu, I. A., \& Napoca, C. N. (2009). Environmental performance versus economic performance. International Journal of Business Research, 9(5), 125-131.

Jovanović, D. S. (2017). Upravljačko računovodstvena podrška procesu upravljanja zaštitom životne sredine (doctoral dissertation), Univerzitet u Kragujevcu, Ekonomski fakultet.

Judge, W. Q., \& Douglas, T. J. (1998). Performance implications of incorporating natural environmental issues into the strategic planning process: An empirical assessment. Journal of management Studies, 35(2), 241-262.

Jugović, J. (2019). Upravljanje troškovima ekološke zaštite u funkciji unapređenja konkurentnosti preduzeća. Ekonomske ideje i praksa, 33, 43-59.

Klassen, R. D., \& Whybark, D. C. (1999). The impact of environmental technologies on manufacturing performance. Academy of Management Journal, 42(6), 599-615.

Krstić, B., \& Sekulić, V. (2020). Upravljanje poslovnim performansama. Niš: Ekonomski fakultet.

Krstić, B., \& Sekulić, V. (2012). Uloga strategijske kontrole u unapređenju poslovnih performansi. Niš: Ekonomski fakultet.

Krstić, B., Jovanović, S., Kahrović, E. (2012) Process-oriented enterprise as a determinant of organization behavior in contemporary business term. Actual Problems of Economics, 11 (137); 369-379

Krstić, B., \& Vučić, S. (2004). Merenje ekoloških performansi preduzeća. Ekonomske teme, 4, 109-116.

Krstić, B., Vučić, S. (2004a). Upravljanje ekološkim performansama preduzeća. Poslovna politika, 53-57 
Lankoski, L. (2000). Determinants of environmental profit: An analysis of the firm-level relationship between environmental performance and economic performance. Helsinki University of Technology.

Marr, B. (2012). Key Performance Indicators (KPI): The 75 measures every manager needs to know. Pearson UK.

Mladenović, M., Arsić, Lj. (2017) Benefiti zelene ekonomije u funkciji povećanja konkurentske prednosti nacionalnih ekonomija, Ekonomski pogledi, 19(2), 8197.

Salo, J. (2008). Corporate governance and environmental performance: Industry and country effects. Competition \& Change, 12(4), 328-354.

Sharman, P. (2001). Using performance architecture to create economic value. Journal of Cost Management, 11 (12), 11-16.

Wagner, M., \& Schaltegger, S. (2003). How does sustainability performance relate to business competitiveness? Greener Management International, 5-16. 